\title{
Sustainable Governance of Marine Stakeholders
}

\author{
Hiroshige Tanaka* \\ Faculty of Economics Chuo University, Japan
}

Submission: October 09, 2019; Published: November 04, 2019

Corresponding author: Hiroshige Tanaka, Faculty of Economics Chuo University, Tokyo, Japan

\begin{abstract}
Sustainability of ecological and social system in the marine needs the structure reform of stakeholders. We employ a classification of stakeholders; inside, outside and external stakeholders to explore the sustainable society in the marine. From the beginning of the 21th century innovation of ICT improves industrial revolution of digital technologies in the proceeding of globalization. In the early stage of the globalization, global corporations do not only increase inside and outside stakeholders within their market network but also accompany rising external stakeholders. It has raised many environmental and social problems into the marine society. The digital revolution can develop the efficient connection between consumers and producers by lowering the transaction cost of markets and improve conservation of marine resources economically and ecologically. Consequently, some external stakeholders are transferring to the outside stakeholders. In addition, displacement of decentralized scheme into markets could decline the social cost of external stakeholders to prevent sustainability of marine societies sufficiently.

Keywords: Digital revolution; Marine ecology and society; Sustainability; Transaction cost; Inside stakeholders; Outside stakeholders; External stakeholders; Decentralized scheme
\end{abstract}

\section{Introduction}

Sustainable systems of marine ecology and society should be constructed by basing on a bottom-line approach ${ }^{1}$. The sustainable systems should enhance communication and cooperation with various stakeholders and perform risk management of marine ecology effectively. The systems aim to conserve diversity of species and prevent destructive changes in ocean environment provocatively. In this essay we explore that the digital revolution partially contributes the construction of sustainable social scheme in marine environments.

Neo liberalists of economics argue that market mechanism could achieve efficient allocation of resources. By pursuing scale merit of market economic transactions have been pervading globally. When we focus on the issues regarding the sustainability of marine ecology, predominant impacts of enlarging globalized economies on marine ecology and fishery should be explored firstly. Corporations in the market mechanism are organized efficiently in the centralized scheme.

Globalization has transformed the structure of stakeholders. Enlargement of economies increases the stakeholders to be relat ed with market transaction and develops range of external effects involving the stakeholders. Globalizing economies make problems of climate change more serious. Raising production and distribution of goods and services in global scales become to emit more pollutants and exploit more marine resources economically and ecologically. From the beginning of the 21th century innovation of ICT accompanys industrial revolution of digital technologies in the proceeding of globalization ${ }^{2}$. The digital revolution can develop the efficient connection between consumers and producers. Tanaka [3] provides the classification of inside, outside and external stakeholders to explore the sustainable scheme for the digitalizing social system ${ }^{3}$.

\section{Digital Revolution in the Marine Ecology and Society}

Marine businesses bring social cost to the related stakehold$\mathrm{ers}^{4}$. The classification makes clear the transformation of marine societies in the digital revolution. The corporations are probable to manage the integrated network of stakeholders. They attempt to construct cooperation with the stakeholders in their networks. The stakeholders in the network of the corporation are divided

${ }^{1}$ Shmelev (6) discusses implications of the bottom-line approach in detail.

${ }^{2}$ Tanaka (2) explores the impact that new industrial revolution affect on the stakeholders.

${ }^{3}$ In practical proposals by UNEP FI and UN Global Compact. (4), Principles of Responsible Investment aims to transfer external stakeholders into outside stakeholders.

${ }^{4}$ Patterson M and B Glavovic (5) surveys that pressures of economies influence on the marine environments. 
into the inside and outside stakeholders. The inside stakeholders such as alliance members, shareholders and creditors obtain stronger or more intimate connections with the corporation than the other outside stakeholders. Development or preservation of marine resources are probable to require a large amount of fund and a long-term investment. The inside stakeholders should construct trusty and united relation with the corporation. The outside stakeholders have relations with the corporation through the market transactions. Digital revolution could enlarge the market transaction by internet communication and lower the transaction costs. Improvement of digital technologies displaces market relations into many intercourses to promote development, preservation and utilization of marine resources. The innovation of digital technologies enhances accuracy to evaluate marine resources and creates new kind of markets. Various types of tourists enjoy marine views by using LCC (low Cost Carriers) and vacation rentals. As the outside stakeholders increase, the evaluation with marine resources and services is available more openly. The corporation makes a supply system to correspond potential demand promptly.
The reconstruction of outside stakeholders is possible to reduce the overconsumption or over development of resources.

By using Figure 1 we can illustrate the changing feature of marine ecology and society in the period of globalization. This figure expresses the social cost that each type of stakeholder to the corporation brings. Imaginary scores are measured in the range between 0 and 200. The social costs of inside and outside stakeholders are compensated by market payments or contracts with the corporation. External stakeholders are needed to owe their social cost in the globalization. Global corporation must confront indirectly with problems from the raising social cost. However, digitalization can enhance corporate performances to be indicated explicitly by summing social costs of the inside and outside stakeholders and induce to decrease the social cost by reforming the structure of market transactions. The fourth right in bar graphs implies that the decentralized system is designed to achieve sustainability and that it should accompany declining production of the corporation.

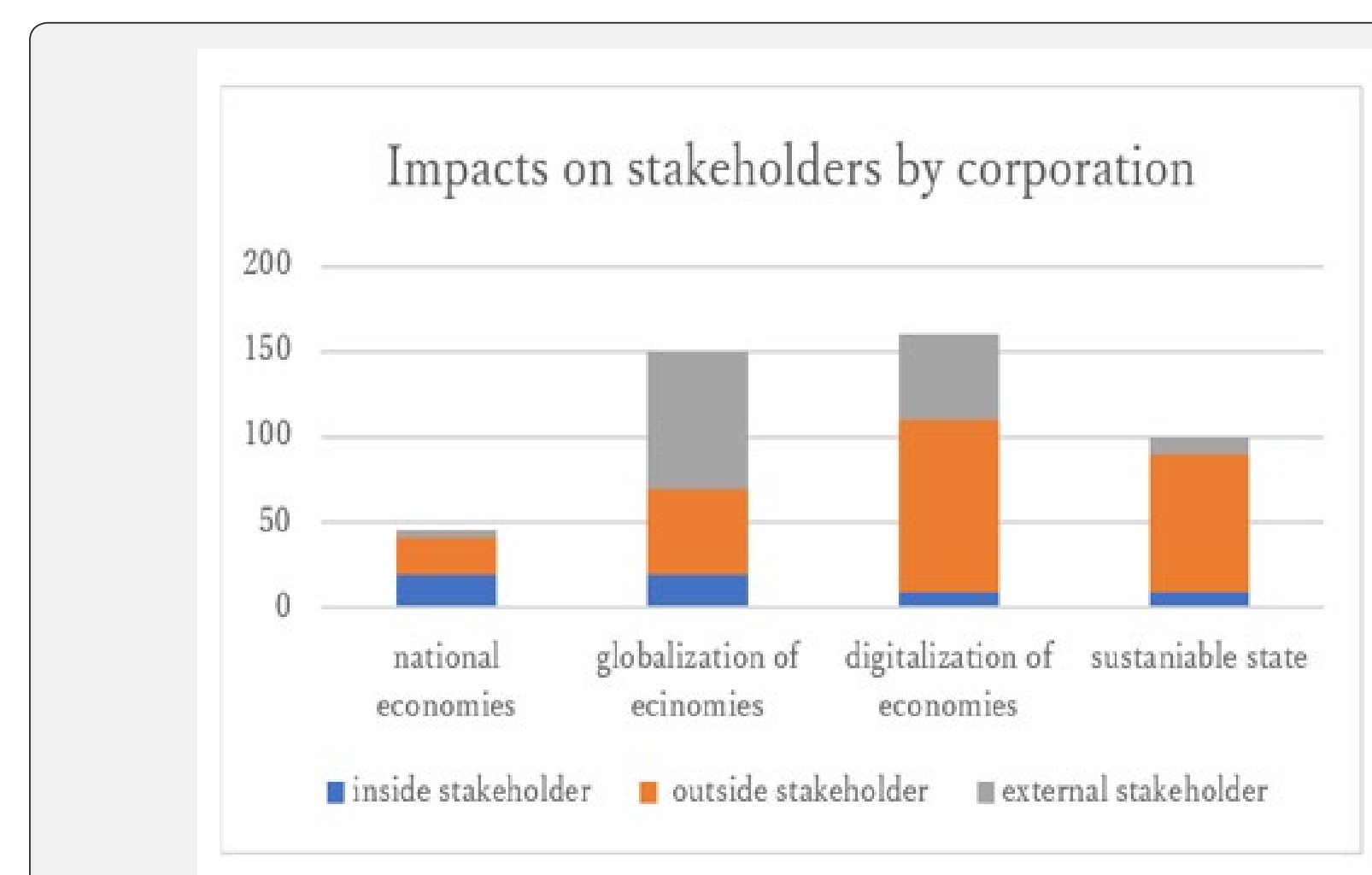

Source : Produced by the author

Figure 1: Stakeholder Impacts and Sustainability .

Although the digital revolution of societies moves a part of external stakeholders into outside stakeholders, the centralized system of corporation has relatively small opportunities to communicate the stakeholders to obtain correct information in the bottom line of ocean environment. Reviews in SNS sometimes present significant knowledge on the local environments. Transaction costs in the digital economies selectively utilize the knowledge and the information on society and environment. While digitalization af- fects to lower the barriers of markets by decreasing costs for a unit of transaction, the corporations are confronted with increasing pressure of enlarging stakeholders to enter the market.

Figure 2 exhibits that sustainable societies and economies should be based on the decentralized system and that an innovation of digital technologies can decrease the social welfare loss generated by enlarging global economies. Innovation of digital 
technologies increases evaluation of marginal social cost by enlarging scope of market transaction moves the curve 0J to 0I upwardly. The innovation shifts the optimal point $\mathrm{K}$ into $\mathrm{D}$ and decreases production from $x^{c}$ to $x_{i}^{c}$. The sustainable point in the decentralized system is indicated by the point $\mathrm{C}$. The digitalization depicts welfare loss presented by area of the triangle CDF but decreases the loss by area of the trapezoid FDKG.

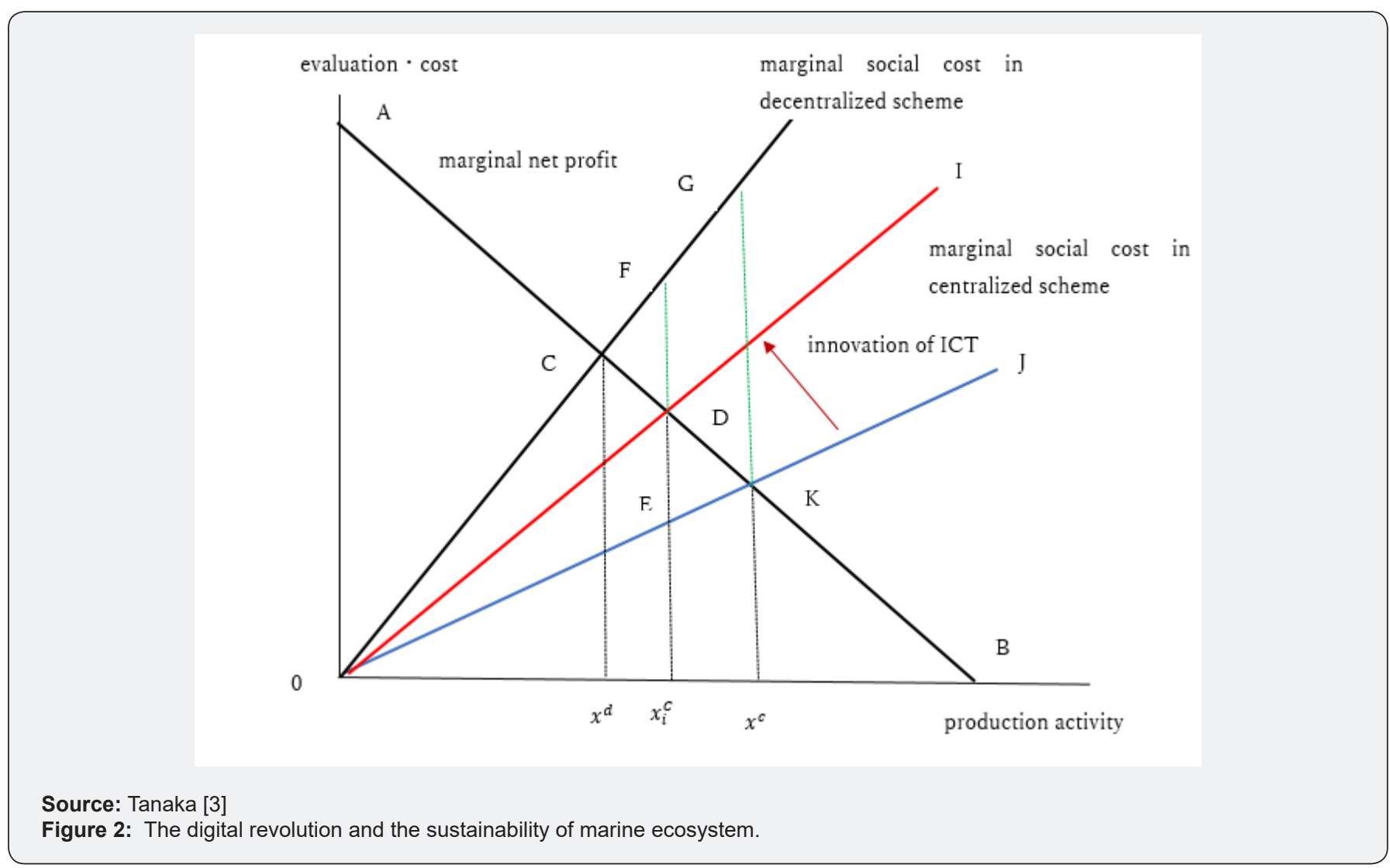

\section{Conclusion}

Coase(1), Williamson(7,8) and other researchers of institutionalism explore how organizations can substitute market systems. The digital revolution has been changing the relation between markets and institutions. To perform integrate governance of economy and ecology in marine societies we should explore sustainable structure of stakeholders. Sustainable system to integrate ecology and society needs significant reforms of stakeholder construction. The digital revolution to facilitate decentralized scheme can decrease the social cost of external stakeholders to cause significant problems on sustainability.

\section{References}

1. Coase RH (1937) The Nature of the Firm. Economica 4(16): 386-405.

2. Tanaka H (2019a) Rehabilitation of the Decentralization in the
Centralizing Process of Global Communities. Journal of Global Issues and Solutions 19(3): 1-18.

3. Tanaka H (2019b) Innovation on the Digital Economies and Sustainability of the Global Communities. Annals of social sciences \& management studies 4(2): 1-10.

4. UNEP FI and UN Global Compact (2016) Principles of Responsible Investment Annual Report 2016.

5. Patterson M and B Glavovic (eds) (2008) Ecological Economics of the Oceans and Coasts, Edward Elgar publishing limited, Cheltenham, UK.

6. Shmelev S (ed) (2017) Green Economy Reader: Lectures in Ecological Economics and Sustainability. Springer, Switzerland.

7. Williamson O E (1975) Markets and Hierarchies: Analysis and Antitrust Implications -A Study in the Economics of Internal Organization. The Free Press, New York.

8. Williamson OE (1986) Economic Organization: Firms, Markets and Policy Control. Wheatsheaf Books, Bringhton, UK. 
cc) (i)

This work is licensed under Creative

Commons Attribution 4.0 Licens

DOI: 10.19080/OFOAJ.2019.10.555805
Your next submission with Juniper Publishers will reach you the below assets

- Quality Editorial service

- Swift Peer Review

- Reprints availability

- E-prints Service

- Manuscript Podcast for convenient understanding

- Global attainment for your research

- Manuscript accessibility in different formats ( Pdf, E-pub, Full Text, Audio)

- Unceasing customer service

Track the below URL for one-step submission

https://juniperpublishers.com/online-submission.php 